Journal of Bangladesh Academy of Sciences, Vol. 37, No. 1, 51-56, 2013

\title{
BIOCHEMICAL AND IMMUNOLOGICAL PARAMETERS OF HEPATITIS B VIRUS POSITIVE PATIENTS IN BANGLADESH
}

\author{
MD. ASADUR RAHMAN, FAHMIDA JAHAN ${ }^{1}$, FARJANA RAHMAN ${ }^{1}$ AND \\ RASHED NOOR ${ }^{*}$
}

Department of Immunology, Popular Diagnostic Centre Ltd., Dhaka-1205, Bangladesh

\begin{abstract}
Present study attempted to detect the biochemical and serological markers other than $\mathrm{HBsAg}$ of Hepatitis B virus (HBV) infection in perspective of Bangladesh. Out of $100 \mathrm{HBsAg}$ positive patients (79 male and 21 female), 23 were found to be $\mathrm{HBeAg}$ positive, and 59 were anti-HBe positive. Nineteen $(24.05 \%)$ and $43(54.43 \%)$ male patients were found to be $\mathrm{HBeAg}$ and anti-HBe positive, respectively; while $4(19.04 \%)$ and 16 (76.19\%) females were $\mathrm{HBeAg}$ and anti-HBe positive, respectively. Three males (3.79\%) had abnormal serum bilirubin, 21 (26.58\%) had abnormal ALT and 9 (11.39\%) had abnormal AST levels; whereas, among the female patients, 1 (4.76\%) had abnormal serum bilirubin, 2 (9.52\%) had abnormal ALT and 1 (4.76\%) had abnormal AST levels. Taken together, present findings suggest that $\mathrm{HBeAg}$ can be used as an alternate marker for detecting the active viral replication in HBV carriers with raised serum ALT levels.
\end{abstract}

Key words: Biochemical, Immunological parameters, Hepatitis B virus

\section{INTRODUCTION}

Hepatitis B virus (HBV) infection is a serious public health problem mainly caused by hepatitis A, B, C, D and E viruses. Approximately two billion people get infected with HBV world-wide (Chakraborty et al. 2011, Hasan et al. 2010). In developing countries like Bangladesh, HBV infections are spreading rapidly due to lack of sufficient health education and vaccination (Hasan et al. 2010). The background study on HBV let us know the parameters used to define and characterize the HBV infection. Such parameters include: HBV antigens and host antibodies; HBV DNA and genotype; biochemical markers, such as alanine aminotransferase (ALT), aspartate aminotransferase (AST), bilirubin; and the degree of hepatic fibrosis and inflammation (Milich and Liang 2003, Sablon and Shapiro 2005). Administration of antiviral therapy depends upon the accurate interpretation of these parameters. Hepatitis B surface antigen (HBsAg) is the hallmark of HBV infection which has been reported to be the first serological marker in acute hepatitis $\mathrm{B}$, and persistence of HBsAg for more than 6 months suggests the onset of chronic HBV infection (Aspinall et al. 2011, Bowden 2002, Matthews and Robotin

\footnotetext{
${ }^{*}$ Corresponding author: <noor.rashed @yahoo.com>.

${ }^{1}$ Department of Microbiology, Stamford University Bangladesh, 51 Siddeswari Road, Dhaka1217, Bangladesh.
} 
2008). However, the presence of HBsAg with clinical and biochemical features of acute hepatitis usually suggests the onset of acute infection in patients from low endemic areas but not in patients from high or intermediate endemic regions. In the latter case, acute and chronic infection may be misdiagnosed if the patient's carrier status is unknown (Han et al. 2008).

Serum HBV DNA and hepatitis B e antigen ( $\mathrm{HBeAg}$ ) are the other two important markers of $\mathrm{HBV}$ infection that are indicative of active viral replication and hence enhancing the risk of transmission of infection (Aspinall et al. 2011). Detecting the serum HBV DNA level is valuable for assessing liver disease activity. Also, differentiating other etiologies of hepatitis activity in HBV carriers, predicting risk of hepatocellular carcinoma development or liver-related mortality, deciding to administer antiviral therapy, measuring the response to antiviral treatment, estimating the risk of developing drug resistance, and detecting the emergence of drug-resistant mutants are the controlling parameters of HBV infection (Sablon and Shapiro 2005). However, an important consideration, especially in perspective of Bangladesh, comes in a way that, in absence of laboratory assessment of viraemic load or failure to detect the presence of HBV DNA, initiation of the therapeutic approach may face a dilemma. In such situation, alternatively, serum $\mathrm{HBeAg}$ among $\mathrm{HBsAg}$ positive patients may be taken as a surrogate marker for the detection of active viral replication and thus justifying the initiation of antiviral chemotherapy without delay.

Based on these suggestive data, present study was attempted to evaluate the biochemical and serological parameters of $\mathrm{HBV}$ positive patients for better understanding of the disease status to enable effective disease intervention in Bangladesh; and also to analyze the underlying risk factors.

\section{MATERIALS AND METHODS}

Blood samples were collected aseptically from $100 \mathrm{HBsAg}$ positive patients prescribed for diagnosis of HBV infection in Popular Diagnostic Centre Ltd. Samples were analyzed to determine the levels of some biochemical parameters including bilirubin, alanine aminotransferase (ALT) and aspartate aminotransferase (AST); and to determine the presence of some immunological parameters including $\mathrm{HBsAg}, \mathrm{HBeAg}$ and Anti-HBe. Dry Biochemistry Random Access Multibatch Analyzer (Vitros 350, J\&J, USA) and Vitros TBIL, ALT and AST slides were used to determine total serum bilirubin, ALT and AST levels, consecutively. All the experiments were carried out according to the manufacturer's instruction (J \& J, USA).

To assess the immunological parameters, Multi Batch Immunoassay Analyzer (ARCHITECT i2000SR, Abbott, USA) was used for qualitative determination of HBsAg, 
$\mathrm{HBeAg}$ and anti-HBeAg. HBsAg was detected in samples using a chemiluminescent micropartical immunoassay (CMIA) technology (VITROS HBsAg assay, J \& J, USA), with flexible assay protocols referred to as Chemiflex. The VITROS HBeAg assay ( $\mathrm{J} \& \mathrm{~J}$, USA) was performed using the Vitros HBeAg reagent pack and vitros immunodiagnostic product- HBeAg calibrator on the VITROS immunodiagnostic system for the detection of HBeAg.

\section{RESULTS AND DISCUSSION}

Impact of age with the presence of $\mathrm{HBeAg}$ and anti-HBeAg: Present study evaluated the serological and biochemical profile of patients with incidentally detected positive HBsAg to assess the risk factors; and hence to determine the disease state for part of better management of $\mathrm{HBV}$ infection by accurate diagnosis and timely initiation of antiviral therapy and by reducing infection transmission in Bangladesh.

In the present study, the population age ranged from 9 - 80 years with a mean of about 34 years (Table 1). Out of $100 \mathrm{HBsAg}$ positive cases, the maximum patients (59 cases) were within the 21 - 40 years age group and the lowest 3 were in 61 - 80 years age group (Table 1). A total of 23 patients were found to be HBeAg positive and among them maximum patients ( 14 cases) were in 21 - 40 years age group and only one patient was in 61 - 80 years age group. On the other hand, a total of 59 patients were found to be anti$\mathrm{HBe}$ positive and among them maximum patients (31 cases) were in 21 - 40 years age group and the lowest 2 were in 61 - 80 years age group.

Table 1. Age distribution of study population with number of $\mathrm{HBeAg}$ and anti-HBe positive cases $(n=100)$.

\begin{tabular}{lllc}
\hline $\begin{array}{c}\text { Age } \\
\text { group }\end{array}$ & $\begin{array}{c}\text { Number of }{ }^{\text {a }} \mathrm{HBsAg} \text { positive } \\
\text { patients }(\%)\end{array}$ & $\begin{array}{c}\text { Number of }{ }^{\mathrm{b}} \mathrm{HBeAg} \\
\text { positive patients }(\%)\end{array}$ & $\begin{array}{c}\text { Number of }{ }^{\mathrm{c}} \text { anti-HBe } \\
\text { positive patients (\%) }\end{array}$ \\
\hline$<21$ & $13(13)$ & $4(30.77)$ & $6(46.15)$ \\
$21-40$ & $59(59)$ & $14(23.73)$ & $31(52.54)$ \\
$41-60$ & $25(25)$ & $4(16)$ & $20(80)$ \\
$61-80$ & $3(3)$ & $1(33.33)$ & $2(66.66)$ \\
Total & $100(100)$ & $23(23)$ & $59(59)$ \\
\hline
\end{tabular}

${ }^{a} \mathrm{HBs}$ Ag: Hepatitis B surface antigen; ${ }^{\mathrm{b}} \mathrm{HBeAg}$ : Hepatitis B e antigen ; ${ }^{\mathrm{c}}$ Anti-HBe: Anti-hepatitis B e.

Thus the study revealed that the age, when infection is acquired, markedly influences the course of disease (Table 1). This finding is also evident from several other studies (Chu et al. 2002, Lai et al. 2003). The chance of developing chronic infection is $90 \%$ or even more among neonates infected with HBV through perinatal transmission. Besides, inactive exposure during adolescence or young adulthood is associated with a $95 \%$ or greater possibility that the disease will be self limiting (Lok and McMahon 2007). 
However, as revealed from Table 1, the higher percentages (59) of anti-HBe positive patients were likely to be chronic carriers.

HBeAg and anti-HBe in defining disease status: Chronic HBV infection characteristically starts with an acute infection indicated by the presence of HBsAg and $\mathrm{HBeAg}$ in the blood serum. HBeAg positivity is a marker of ongoing viral replication and also indicates higher viral load and infectivity; and may persist for months to years. Moreover, those who are $\mathrm{HBeAg}$ positive are better responders to antiviral drugs (Saikia et al. 2007). It is known that mothers who are HBsAg positive particularly those who are also $\mathrm{HBeAg}$ positive, are much more likely than others to transmit $\mathrm{HBV}$ to their offsprings (Lok and McMahon 2007).

In the present study, out of $79 \mathrm{HBsAg}$ positive males and $21 \mathrm{HBsAg}$ positive females, 24.05 and $19.04 \%$ were $\mathrm{HBeAg}$ positive males and females, respectively. On the other hand, 54.43 and $76.19 \%$ were anti-HBe positive males and females, respectively. HBeAg positivity was found to be higher in male patients than that in female patients (Table 2). Thus, HBeAg positive females found in this study might have greater potential for viral transmission and disease spread. It has been reported that patients who were $\mathrm{HBeAg}$-positive had significantly more ascites and acquire jaundice compared with the HBeAg-negative group (Niederau et al. 1996). A study conducted in Pakistan reported that among the $\mathrm{HBsAg}$ positive cases, $21.4 \%$ were $\mathrm{HBeAg}$ positive and $78.6 \%$ were HBeAg negative (Khokhar and Gill 2004). This result is similar with that of the present study indicating the greater as well as consistent number of $\mathrm{HBeAg}$ negative patients (77\%) and the possibility of seroconversion from $\mathrm{HBeAg}$ to anti-HBe.

Table 2. Sex distribution of study population and number of $\mathrm{HBeAg}$ positive and anti-HBe positive patients $(n=100)$.

\begin{tabular}{lccc}
\hline Sex & $\begin{array}{c}\text { Number of }{ }^{\mathrm{a}} \mathrm{HBsAg} \text { positive } \\
\text { patients }(\%)\end{array}$ & $\begin{array}{c}\text { Number of }{ }^{\mathrm{b}} \mathrm{HBeAg} \\
\text { positive patients }(\%)\end{array}$ & $\begin{array}{c}\text { Number of }{ }^{\mathrm{c}} \text { anti-HBe } \\
\text { positive patients (\%) }\end{array}$ \\
\hline Male & $79(79)$ & $19(24.05)$ & $43(54.43)$ \\
Female & $21(21)$ & $4(19.04)$ & $16(76.19)$ \\
Total & $100(100)$ & $23(23)$ & $59(59)$ \\
\hline
\end{tabular}

${ }^{\mathrm{a}} \mathrm{HBs} A \mathrm{~g}$ : Hepatitis B surface antigen; ${ }^{\mathrm{b}} \mathrm{HBeAg}$ : Hepatitis B e antigen ; ${ }^{\mathrm{c} A n t i-H B e: ~ A n t i-h e p a t i t i s ~ B ~ e . ~}$

Correlation of biochemical parameters with serological markers: Moreover, in adult acquired disease, early phase of infection is often accompanied by significant disease activity with elevated ALT levels in comparison with those who acquired the infection perinatally. Many patients with perinatal infection develop HBeAg positive chronic hepatitis with elevated ALT levels after 10 - 30 years of infection. $30-40 \%$ of the $\mathrm{HBeAg}$ negative chronic HBV patients experience persistent elevated ALT levels (three to four-folds) and the remaining 60 - 70\% can have erratic ALT patterns (Cheung 2006). 
According to Rabbi et al. (2008), 92.85\% HBeAg positive patients with or without raised ALT were found with active viral replication. Another study showed that HBeAgpositive patients had much higher levels of ALT and AST (Saikia 2007).

In this study, out of 79 positive males, 3, 21 and 9 patients were found to have elevated bilirubin, ALT and AST levels, consecutively. Whereas, out of 21 positive females, 2 were found to have increased ALT level; and only 1 was found to have abnormal bilirubin and AST levels (Table 3). Thus, the findings of our study showed a lower number of patients (23\%) with elevated ALT level; and presence of abnormal AST and bilirubin was not significantly enough (10 and 4\%, respectively).

Table 3. Number of abnormal bilirubin, ALT and AST with percentage and sex distribution of the study patients.

\begin{tabular}{llccc}
\hline Sex & ${ }^{\mathrm{a}} \mathrm{HBs}$ Ag positive & Abnormal bilirubin & Abnormal $^{\mathrm{b}}$ ALT & Abnormal $^{\mathrm{c}}$ AST \\
\hline Male & $79(79)$ & $3(3.79)$ & $21(26.58)$ & $9(11.39)$ \\
Female & $21(21)$ & $1(4.76)$ & $2(9.52)$ & $1(4.76)$ \\
Total & $100(100)$ & 4 & 23 & 10 \\
\hline
\end{tabular}

${ }^{a} \mathrm{HBs} A g$ : Hepatitis B surface antigen; ${ }^{\mathrm{b}} \mathrm{ALT}$ : Alanine aminotransferase; ${ }^{\mathrm{c}}$ AST: Aspartate aminotransferase.

The current investigation revealed that sero-conversion of $\mathrm{HBeAg}$ to anti $\mathrm{HBe}$ may be correlated with the decrease or normalization of serum ALT concentration and a very low level of viremia. It is also recommended that detectable $\mathrm{HBeAg}$ should be considered as a surrogate marker for HBV DNA in HBV carriers with raised serum ALT when detection of HBV genome is not possible. Moreover, further study should be carried out with more HBsAg positive patients who fulfill the criteria to be labeled as chronic viral hepatitis and comparison should be made with biochemical and immunological parameters in individual cases.

\section{ACKNOWLEDGEMENTS}

The authors are thankful to Professor Samir K. Shaha, Department of Microbiology, Bangladesh Institute of Child Health, for his kind help in conducting this study. The work was financed by Stamford University Bangladesh and Popular Diagnostic Centre Ltd., Dhaka.

\section{REFERENCES}

Aspinall, E. J., G. Hawkins, A. Fraser, S. J. Hutchinson and D. Goldberg. 2011. Hepatitis B prevention, diagnosis, treatment and care: A review. Occupational Medicine 61: 531-540.

Bowden, S. 2002. Laboratory diagnosis of hepatitis B infection. In: Hepatitis B Virus. (Ed. Lai, C. L. and S. Locarnini). International Medical Press, London, UK. pp. 145-159. 
Cheung, T. K., C. L. Lai, B. C. Y. Wong, J. Fung and M. F. Yuen. 2006. Clinical features, biochemical parameters, and virological profiles of patients with hepatocellular carcinoma in Hong Kong. Aliment. Pharmacol. Therap. 24: 573-583.

Chu, C. J., M. Hussain and A. S. F. Lok. 2002. Quantitative serum HBV DNA levels during different stages of chronic hepatitis B infection. Hepatology 36: 1408-1415.

Han, Y., Q. Tang, W. Zhu, X. Zhang and L. You. 2008. Clinical, biochemical, immunological and virological profiles of and differential diagnosis between, patients with acute hepatitis B and chronic hepatitis B with acute flare. J. Gastroenterol. Hepatol. 23: 1728-1733.

Hasan, A., H. A. Nur, R. Christian, B. Abdullah, B. Pradip, H. Lokman, A. S. Mohammed, S. H. Mohammed, B. Christoph and G. Niklaus. 2010. Prevalence and risk factors of hepatitis B and $\mathrm{C}$ virus infections in an impoverished urban community in Dhaka, Bangladesh. BMC. Infect. Dis. 10: 208.

Islam, M. D. U., R. U. Ahmed, S. G. Kibria, M. T. Hossain, M. K. Biswas, M. S. R. Bhuiyan, N. U. Ahmed and N. Haq. 2010. Clinical Significance of Serum HbeAg Among HbsAg Positive Patients. Faridpur Med. College J. 5: 50-52.

Khokhar, N. and L. M. Gill. 2004. Serolological profile of incidentally detected asymptomatic HBsAg positive subjects (IDAHS). J. Coll. Physicians Surg. Pak. 14: 208-10.

Lai, C. L., V. Ratziu, M. Yuen and T. Poynard. 2003. Viral hepatitis B. Lancet 362: 2089-2094.

Lok, A. S. and B. J. McMahon. 2007. Chronic hepatitis. Hepatology 45: 507-539.

Matthews, G. and M. Robotin. 2008. B Positive - all you wanted to know about hepatitis B: A guide for primary care providers. Australasian Society for HIV Medicine (ASHM), pp. 31-39.

Milich, D. and T. J. Liang. 2003. Exploring the biological basis of hepatitis B e antigen in hepatitis B virus infection. Hepatology 38: 1075-86.

Niederau, C., T. Heintges, S. Lange, G. Goldman, C. M. Niederau, L. Mohr and D. Haussinger. 1996. Long-term follow-up of HBeAg-positive patients treated with interferon alfa chronic Hepatitis B. N. Eng. J. Med. 334: 1422-1427.

Rabbi, F. J., M. K. Rezwan and T. Shirin. 2008. HBeAg/anti-HBe, alanine aminotransferase and HBV DNA levels in HBsAg positive chronic carriers. Bangladesh Med. Res. Council Bull. 34: $39-43$.

Sablon, E. and F. Shapiro 2005. Advances in Molecular Diagnosis of HBV Infection and Drug Resistance. Int. J. Med. Sci. 2: 8-16.

Saikia, N., R. Talukdar, S. Mazumder, S. Khanna and R. Tandon. 2007. Management of patients with HBeAg-negative chronic hepatitis B. Postgrad. Med. J. 83(975): 32-39. 